\title{
Effect of a platelet-activating factor (PAF) antagonist, SR 27417A, on PAF-induced gas exchange abnormalities in mild asthma
}

\author{
F.P. Gómez*, J. Roca*, J.A Barberà*, K.F. Chung+, V.I. Peinado*, R. Rodriguez-Roisin*
}

Effect of a platelet-activating factor (PAF) antagonist, SR 27417A, on PAF-induced gas exchange abnormalities in mild asthma. F.P. Gómez, J. Roca, J.A Barberà, K.F. Chung, V.I. Peinado, R. Rodriguez-Roisin. (CERS Journals Ltd 1998.

ABSTRACT: Inhaled platelet-activating factor (PAF), both in normals and in asthmatic patients, provokes transient systemic effects, neutropenia, bronchoconstriction and arterial oxygenation abnormalities similar to those shown in spontaneous exacerbations of asthma.

To investigate the efficacy of a new PAF-receptor antagonist, SR 27417A, on all these changes after PAF challenge, 12 nonsmoking patients (four females and eight males) (mean \pm SEM) age $24 \pm 1$ yrs with mild asthma (forced expiratory volume in one second (FEV1) $93 \pm 3 \%$ predicted) were studied in a double-blind, placebo-controlled, cross-over fashion 2 weeks apart. PAF aerosol challenge $(18 \mu \mathrm{g})$ was carried out $3 \mathrm{~h}$ after oral administration of either SR 27417A $(20 \mathrm{mg})$ or placebo. Respiratory system resistance $(R \mathrm{rs})$ and arterial blood gases and neutrophil cell counts were measured at baseline, before compound/placebo administration, and at 5, 15 and $45 \mathrm{~min}$ after PAF.

Compared to vehicle, SR 27417A brought about moderate attenuation of PAFinduced neutropenia at 5 min $($ by $140 \% ; p<0.025)$, and rebound neutrophilia at 15 and $45 \mathrm{~min}(\mathrm{p}<0.025)$, increases of $R$ rs $($ by $90-65 \%)(p<0.01)$ and of alveolar-arterial

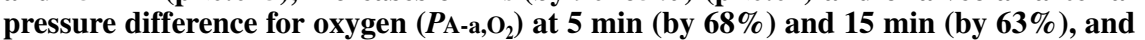
decreases of arterial oxygen tension $\left(P \mathrm{a}, \mathrm{O}_{2}\right)$ at $5 \mathrm{~min}(\mathrm{by} 57 \%$; $\mathrm{p}<0.025$, each). Furthermore, systemic effects and platelet aggregation tests $(p<0.001)$ were abolished after the administration of the compound.

We conclude that SR 27417A is effective in inhibiting systemic, cellular and pulmonary effects after platelet-activating factor challenge in patients with mild bronchial asthma.

Eur Respir J 1998; 11: 835-839.
*Servei de Pneumologia i Al.lergia Respiratoria, Departament de Medicina, Hospital Clinic, Universitat de Barcelona, Barcelona, Spain. +National Heart and Lung Institute, Imperial College, School of Medicine, London, UK.

Correspondence: R. Rodriguez-Roisin

Servei de Pneumologia i Al.lèrgia Respiratòria, Hospital Clínic, Villarroel, 170, 08036 Barcelona, Spain

Fax: 3432275404

Keywords: Bronchial asthma, mediators of lung inflammation, PAF receptor antagonist, pulmonary gas exchange, pulmonary mechanics

Received: September 21997

Accepted after revision January 201998

Supported by grants $94 / 0986$ and $97 / 0126$ from the Fondo de Investigación Sanitaria (FIS) and the Comissionat per a Universitats i Recerca de la Generalitat de Catalunya (1995 SGR 00446) and an educational grant from Sanofi Winthrop, SA FPG was supported by a Predoctoral Research Fellowship from the European Respiratory Society (ERS) (1996).
Platelet-activating factor (PAF) [1] is a potent etherlinked phospholipid mediator of inflammation which is considered to have a potential role in the pathogenesis of bronchial asthma. Recently, we have shown that PAF (dosage range $24-12 \mu \mathrm{g}$ ) disturbed pulmonary gas exchange in normal individuals [2-4] and in patients with mild asthma $[5,6]$ in an identical manner to the entire spectrum of ventilation-perfusion $\left(V^{\prime} \mathrm{A} / Q^{\prime}\right)$ mismatching shown in patients with bronchial asthma $[7,8]$. We suggested that the $V^{\prime} \mathrm{A} / Q^{\prime}$ defects could be preferentially related to an augmented bronchial vascular permeability due to post-capillary venoconstriction induced by PAF, thereby supporting the notion that PAF may play a key role, as a putative potent mediator of inflammation in human airways $[5,8]$. However, negative results have been obtained over the last few years, in stable patients with mild to moderate asthma with different PAF antagonists, and these question the role of PAF in the pathobiology of asthma.

The compound SR 27417A (N-(2-dimethylaminoethyl)-N-(pyridinylmethyl)(4-(2,4,6 triisopropylphenyl) thiazol-2-yl)) amine difumarate is a novel class of anti-PAF medication that has been shown to be a potent, long-lasting and selective second generation PAF antagonist [9, 10]. The present study was undertaken to assess the efficacy of this new PAF receptor antagonist, SR 27471A, in attenuating or preventing the PAF-induced systemic, neutropenic, lung mechanical and pulmonary gas exchange effects observed in patients with mild asthma [5, 6]. To our knowledge, the efficacy of this class of anti-asthma compounds on pulmonary gas exchange abnormalities provoked by PAF has not been investigated previously.

\section{Methods}

\section{Study population}

Twelve patients with mild asthma (table 1) were recruited from our Outpatient Department for the study, which was approved by the Ethical Research Committee of the Hospital Clinic. All subjects gave informed written consent after the purpose, risks and potential benefits of the study were explained to them. The inclusion criteria were: no respiratory infection or exacerbation of asthma within the preceding 6 weeks; forced expiratory volume in one second (FEV1) S80\% predicted and positive methacholine bronchial challenge; maintenance therapy with aerosol short-acting beta-adrenergics and/or inhaled corticosteroids, but no previous treatment with oral corticosteroids; and absence of any systemic or cardiopulmonary disease 
Table 1. - Anthropometric and baseline function data on SR 27417A and placebo studies

\begin{tabular}{|c|c|c|}
\hline Subjects $n$ & \multicolumn{2}{|c|}{12} \\
\hline Age yrs & \multicolumn{2}{|c|}{$24 \pm 1$} \\
\hline Sex F/M & \multicolumn{2}{|c|}{$4 / 8$} \\
\hline Height $\mathrm{cm}$ & \multicolumn{2}{|c|}{$170 \pm 3$} \\
\hline Weight $\mathrm{kg}$ & \multicolumn{2}{|c|}{$69 \pm 3$} \\
\hline FEV1 L & \multicolumn{2}{|c|}{$3.8 \pm 0.2$} \\
\hline FEV1 \% & \multicolumn{2}{|c|}{$93 \pm 3$} \\
\hline FEV1/FVC \% & \multicolumn{2}{|c|}{$76 \pm 2$} \\
\hline PD20 $\mu \mathrm{mol}$ & \multicolumn{2}{|c|}{$0.3 \pm 0.1$} \\
\hline & SR 27417A & Placebo \\
\hline Neutrophils $\times 10^{9} \cdot \mathrm{L}^{-1}$ & $2.9 \pm 0.2$ & $3.1 \pm 0.3$ \\
\hline$V^{\prime} \mathrm{E} \mathrm{L} \cdot \mathrm{min}^{-1}$ & $8.2 \pm 1.3$ & $7.9 \pm 0.6$ \\
\hline$f_{\mathrm{R}}$ breaths $\cdot \mathrm{min}^{-1}$ & $14 \pm 1$ & $14 \pm 2$ \\
\hline$R \mathrm{rs} \quad \mathrm{cmH}_{2} \mathrm{O} \cdot \mathrm{L}^{-1} \cdot \mathrm{s}$ & $3.6 \pm 0.4$ & $3.2 \pm 0.3$ \\
\hline$P_{\text {sys }} \mathrm{mmHg}$ & $89 \pm 3$ & $88 \pm 2$ \\
\hline$f_{\mathrm{C}}$ beats $\cdot \mathrm{min}^{-1}$ & $72 \pm 2$ & $70 \pm 2$ \\
\hline $\mathrm{Pa}_{\mathrm{a}} \mathrm{O}_{2} \mathrm{mmHg}$ & $99 \pm 4$ & $98 \pm 3$ \\
\hline $\mathrm{Pa}_{\mathrm{a}, \mathrm{CO}_{2} \mathrm{mmHg}}$ & $38 \pm 1$ & $38 \pm 1$ \\
\hline $\mathrm{pH}$ & $7.42 \pm 0.01$ & $7.42 \pm 0.01$ \\
\hline$P \mathrm{~A}-\mathrm{a}, \mathrm{O}_{2} \mathrm{mmHg}$ & $5.8 \pm 1.8$ & $6.2 \pm 2.3$ \\
\hline$V^{\prime} \mathrm{O}_{2} \mathrm{~mL} \cdot \mathrm{min}^{-1}$ & $256 \pm 12$ & $245 \pm 11$ \\
\hline$V^{\prime} \mathrm{CO}_{2} \mathrm{~mL} \cdot \mathrm{min}^{-1}$ & $218 \pm 22$ & $215 \pm 17$ \\
\hline
\end{tabular}

Values are absolute number, or mean \pm SEM. For arterial blood gases, $\mathrm{n}=10$. F: female; $\mathrm{M}$ : male; $\mathrm{FEV} 1$ : forced expiratory volume in one second; FVC: forced vital capacity; PD20: provocative dose of methacholine causing FEV1 to fall $20 \%$ from baseline; $V$ 'E: minute ventilation; $f \mathrm{R}$ : respiratory frequency; $R \mathrm{rs}$ : resistance of the respiratory system; $P$ sys: mean systemic arterial pressure; $f \mathrm{C}$ : cardiac frequency; $P \mathrm{a}, \mathrm{O}_{2}:$ arterial oxygen tension; $\mathrm{Pa}_{\mathrm{a}} \mathrm{CO}_{2}:$ arterial carbon dioxide tension; $P \mathrm{~A}-\mathrm{a}, \mathrm{O}_{2}$ : alveolar-arterial pressure difference for oxygen; $V^{\prime} \mathrm{O}_{2}$ : oxygen consumption; $V^{\prime} \mathrm{CO}_{2}$ : carbon dioxide production. $1 \mathrm{mmHg}=0.133 \mathrm{kPa}$.

other than asthma. All subjects were nonsmokers and all but one were atopic as judged by the presence of a positive response to skin tests to one or more common aeroallergens.

\section{Measurements}

Blood samples were collected anaerobically through a catheter inserted into the radial artery. Arterial oxygen and carbon dioxide tensions ( $\mathrm{Pa}, \mathrm{O}_{2}$ and $\mathrm{Pa}_{\mathrm{a}} \mathrm{CO}_{2}$, respectively) and $\mathrm{pH}$ were analysed using standard electrodes (IL 1302; Instrumentation Laboratories, Milano, Italy). Haemoglobin concentration was measured by a Co-oximeter (IL 482; Instrumentation Laboratories, Milano, Italy). Oxygen uptake $\left(V^{\prime} \mathrm{O}_{2}\right)$ and $\mathrm{CO}_{2}$ production $\left(V^{\prime} \mathrm{CO}_{2}\right)$ were calculated from mixed expired $\mathrm{O}_{2}$ and $\mathrm{CO}_{2}(\mathrm{CPX}$ System; Medical Graphics, St Paul, MN, USA). Minute ventilation ( $\left.V^{\prime} E\right)$ and respiratory frequency $(f \mathrm{R})$ were measured using a calibrated Wright spirometer (Respirometer MK8; BOC-Medical, Essex, UK). The alveolar-arterial pressure difference for oxygen $\left(P \mathrm{~A}-\mathrm{a}, \mathrm{O}_{2}\right)$ was calculated according to the alveolar gas equation using the measured respiratory exchange ratio (RER).

Total white cell counts in arterial blood were measured with a Technicon H.1 ${ }^{\text {TM }}$ System (Technicon, Tarytown, NY, USA). For measurements of platelet aggregation, arterial blood $(9 \mathrm{~mL})$ was collected and centrifuged at $150 \times \mathrm{g}$ for $20 \mathrm{~min}$ at room temperature to obtain the platelet-rich plasma (PRP). Aggregation was induced by addition to the PRP of the stated concentration of PAF or adenosine diphosphate (ADP). The maximal aggregation of the PRP was recorded over a period of $\sim 5 \mathrm{~min}$ (Hitachi/Aggrecorder PA3210, Kyoto, Japan) and measurements were expressed as percentages of the maximal aggregation. Inhibition of PAF-induced aggregation in post-treatment samples was calculated as a percentage of the maximal aggregation to PAF in PRP obtained from blood samples withdrawn before intake of SR 27417A/vehicle.

Total resistance of the respiratory system $(R \mathrm{rs})$ was measured by the forced oscillation technique and its analysis restricted to $8 \mathrm{~Hz}$, as reported in detail elsewhere [11, 12]. A three-lead electrocardiogram, cardiac frequency $(f \mathrm{C})$ and systemic pressure $\left(P_{\text {sys }}\right)$ and arterial oxygen saturation $\left(\mathrm{Sa}_{\mathrm{a}} \mathrm{O}_{2}\right)$ through a pulsioximeter (HP M1166A; Hewlett-Packard, Boblingen, Germany) were continuously recorded throughout the whole study (HP 7830A Monitor and HP 7754B Recorder; Hewlett-Packard, Waltham, MA, USA).

\section{Study design}

A randomized double-blind, placebo-controlled, crossover design was used. All patients were challenged on two occasions, 2 weeks apart, with inhaled PAF after the administration of either $20 \mathrm{mg}$ of oral SR 27417A or placebo (lactose) with patients breathing room air and seated in an armchair. Asthma medication was withheld for $12 \mathrm{~h}$ before arrival in the laboratory. After the establishment of adequate steady-state conditions, a set of duplicate measurements of arterial blood respiratory gases and white blood cell counts and of ventilatory, haemodynamic and $R$ rs was carried out (baseline). Maintenance of steadystate conditions after PAF challenge was demonstrated by stability $( \pm 5 \%)$ of both ventilatory and haemodynamic variables, and by the close agreement between duplicate measurements of mixed expired and arterial $\mathrm{O}_{2}$ and $\mathrm{CO}_{2}$ (within $\pm 5 \%$ ). These conditions were met in all patients throughout the study period. Likewise, a test of platelet aggregation was carried out before and $3 \mathrm{~h}$ after either SR 27417A or vehicle.

Three hours after compound/placebo administration, the patient was challenged with PAF $\left(\mathrm{C}_{16}\right)$ (1-O-hexadecyl-2-acetyl-sn-glycero-3-phosphocholine) $(18 \mu \mathrm{g})$ (Novabiochem AG, Laufelfingen, Switzerland). The preparation of the PAF solution and details of the PAF challenge have been reported in full elsewhere [2-6]. Duplicate measurements were taken then at 5, 15 and 45 min following PAF inhalation, as described previously [2-6]. All sets of measurements consisted of the following steps in sequence: ventilatory recordings; respiratory gas and circulating white blood cell samplings; and haemodynamic and Rrs measurements.

\section{Statistical analysis}

The results are expressed as mean \pm SEM and $95 \%$ confidence interval. All the analyses were performed with version 6.0.1. of the Statistical Package for the Social Sciences (SPSS), (SPSS Inc., Chicago, IL, USA). Both the effects of PAF challenge and pretreatment with SR 27417A or placebo on white cell counts and arterial and mixed expired blood gases, ventilatory and haemodynamic variables and $R$ rs were assessed by a two-way repeated analysis of variance (ANOVA). Whenever an interaction between 
the effects of PAF challenge and those of treatment was found, mean differences between SR 27417A and placebo at each time point were analysed using paired t-test corrected for multiple comparisons. Likewise, paired t-test was used to assess differences in platelet aggregation before and after drug/placebo administration. Pearson's correlations were used when appropriate to assess relationships between variables. Significance was set at pð0.05 in all instances.

\section{Results}

\section{Baseline data before PAF}

Mean anthropometric and functional measurements and baseline values are presented in table 1 . All were similar to those reported in our previous investigations $[5,6]$ with no differences between SR 27417A and placebo studies. Platelet aggregation tests at $40 \mathrm{nM}$ PAF (from $69 \pm 8 \%$ to $6 \pm 1 \%$ ) and $80 \mathrm{nM}$ PAF (from $79 \pm 7 \%$ to $6 \pm 1 \%$ ) were significantly abolished (both $\mathrm{p}<0.001) 3 \mathrm{~h}$ after oral administration of the compound, but not after vehicle (from $60 \pm 7 \%$ to $63 \pm 7 \%$ and from $73 \pm 7 \%$ to $76 \pm 7 \%$, respectively).

\section{Effects of PAF after placebo (table 2 and fig. 1)}

All but three patients noticed facial flushing, three coughed and two felt shortness of breath immediately after PAF challenge. Compared with pretreatment with SR 27417A, circulating peripheral blood neutrophils fell in all but three patients at $5 \mathrm{~min}(\mathrm{p}<0.025)$ after PAF inha- lation, followed by a rebound neutrophilia in 11 of them at 15 and $45 \mathrm{~min}(\mathrm{p}<0.025)$. Total $R$ rs increased in all but two patients at $5 \mathrm{~min}$, an increase which persisted 15 and 45 min after PAF challenge $(\mathrm{p}<0.01)$. As for arterial blood gas abnormalities $(\mathrm{n}=10), \mathrm{Pa}_{\mathrm{a}} \mathrm{O}_{2}$ decreased at $5 \mathrm{~min}$ in all patients $(\mathrm{p}<0.025)$, a finding probably explained by the development of $V^{\prime} \mathrm{A} / Q^{\prime}$ mismatch provoked by inhaled PAF as shown previously [2-6]; similarly, the increases in $P A-a, \mathrm{O}_{2}$ were significant at 5 and 15 min after PAF challenge $(\mathrm{p}<0.025$ each). By contrast, ventilatory and haemodynamic variables and the other gas exchange indices, including arterial $\mathrm{pH}$, did not change.

Effects of SR 27471A on PAF challenge (table 2 and fig. 1)

Compared with vehicle, pretreatment with SR 27471A effectively abolished PAF-induced systemic effects: cough and dyspnoea were prevented in all patients, while facial flushing was only observed in one. In addition, the PAFinduced decrease of peripheral neutrophil counts at $5 \mathrm{~min}$ (by $140 \%$ ) and the subsequent rebound neutrophilia observed at 15 and 45 min were completely offset in all but one patient. Equally important, PAF-induced lung function abnormalities were also blocked to a moderate to profound extent. Thus, pretreatment with SR 27471A prevented the increase in $R$ rs in half of the patients over the whole period of study (by $90-65 \%$ ), while the $P \mathrm{a}, \mathrm{O}_{2}$ reductions at 5 min (by 57\%) in all but three patients and the increases of $\mathrm{PA}-\mathrm{a}, \mathrm{O}_{2}$ at $5 \mathrm{~min}$ (by $68 \%$ ) and $15 \mathrm{~min}($ by $63 \%$ ) in all but five patients were attenuated when compared to vehicle pretreatment.

There were no significant correlations between the changes in the different lung function variables and cellular abnormalities after PAF.

Table 2. - Effects of SR $27417 \mathrm{~A} /$ placebo on platelet activating factor (PAF) challenge $(n=12)$

\begin{tabular}{|c|c|c|c|c|c|c|c|}
\hline & \multicolumn{6}{|c|}{ Difference from baseline } & \multirow[b]{2}{*}{ p-value } \\
\hline & \multicolumn{2}{|r|}{$5 \mathrm{~min}$} & \multicolumn{2}{|r|}{$15 \mathrm{~min}$} & \multicolumn{2}{|r|}{$45 \mathrm{~min}$} & \\
\hline \multicolumn{8}{|c|}{ Neutrophils $\times 10^{9}$ cells $\cdot \mathbf{L}^{-1}$} \\
\hline Placebo & -1.5 & $(-2.6--0.4)$ & 1.5 & $(0.5-2.4)$ & 2.1 & $(0.8-3.3)$ & 0.01 \\
\hline SR 27417A & $0.6^{+}$ & $(0.2-1.0)$ & 0.7 & $(0.2-1.1)$ & $0.6^{+}$ & $(0.2-1.0)$ & \\
\hline \multicolumn{8}{|l|}{$V^{\prime} \mathbf{E} \mathbf{L} \cdot \mathbf{m i n}-1$} \\
\hline Placebo & 0.7 & $(-0.2-1.7)$ & 0.7 & $(-0.1-1.5)$ & 0.1 & $(-9.0-1.1)$ & NS \\
\hline SR 27417A & -0.6 & $(-3.0-1.7)$ & -0.4 & $(-2.6-1.7)$ & -0.5 & $(-2.9-1.9)$ & \\
\hline \multicolumn{8}{|c|}{$f_{\mathrm{R}}$ breaths $\cdot \mathrm{min}^{-1}$} \\
\hline Placebo & 0.6 & $(-0.7-1.8)$ & 0.3 & $(-1.1-1.8)$ & -0.4 & $(-1.8-1.0)$ & NS \\
\hline SR 27417A & 0 & $(-1.1-1.1)$ & -0.2 & $(-1.3-0.9)$ & 0.5 & $(-1.1-2.1)$ & \\
\hline \multicolumn{8}{|c|}{$\operatorname{Rrs} \mathrm{cmH}_{2} \mathrm{O} \cdot \mathrm{L}^{-1} \cdot \mathrm{s}$} \\
\hline Placebo & 2.0 & $(0.8-3.1)$ & 1.7 & $(0.4-3.0)$ & 1.0 & $(0.1-1.9)$ & 0.006 \\
\hline SR 27417A & 0.7 & $(0.2-1.3)$ & 0.6 & $(0.1-1.2)$ & 0.1 & $(-0.4-0.6)$ & \\
\hline \multicolumn{8}{|l|}{$\mathrm{Pa}_{\mathrm{a}} \mathrm{O}_{2} \mathrm{mmHg}$} \\
\hline Placebo & -27.1 & $(-36.3--17.9)$ & -17.1 & $(-27.9--7.2)$ & -6.8 & $(-14.3--0.7)$ & 0.004 \\
\hline SR 27417A & $-11.7+$ & $(-21.4--1.9)$ & -9.2 & $(-16.4--2.0)$ & -5.6 & $(-12.8-1.6)$ & \\
\hline \multicolumn{8}{|l|}{$\mathrm{Pa}_{\mathrm{a}, \mathrm{CO}_{2}} \mathrm{mmHg}$} \\
\hline Placebo & -0.4 & $(-1.6-0.7)$ & -0.6 & $(-2.5-1.3)$ & -0.9 & $(-2.9-1.0)$ & NS \\
\hline SR 27417A & -0.6 & $(-2.1-1.0)$ & 0.3 & $(-0.9-1.4)$ & -0.3 & $(-1.5-1.0)$ & \\
\hline \multicolumn{8}{|c|}{${\mathrm{PA}-\mathrm{a}, \mathrm{O}_{2}}_{2} \mathbf{m m H g}$} \\
\hline Placebo & 29.3 & $(19.6-38.9)$ & 15.8 & $(7.7-23.9)$ & 6.5 & $(2.3-10.8)$ & 0.004 \\
\hline SR 27417A & 9.4 & $(0.5-18.3)$ & $5.8^{+}$ & $(-0.7-12.3)$ & 3.6 & $(-1.7-8.9)$ & \\
\hline
\end{tabular}

For arterial blood gases, $\mathrm{n}=10$. Values are means, and $95 \%$ confidence intervals in parentheses. ${ }^{+}: \mathrm{p}<0.025$ for comparison with placebo; : significance of the interaction between the effects of PAF challenge and pretreatment with SR 27417A/placebo; significance of the effect of treatment (SR 27417A versus placebo) calculated by repeated measures analysis of variance. For definitions of abbreviations, see table 1 . 

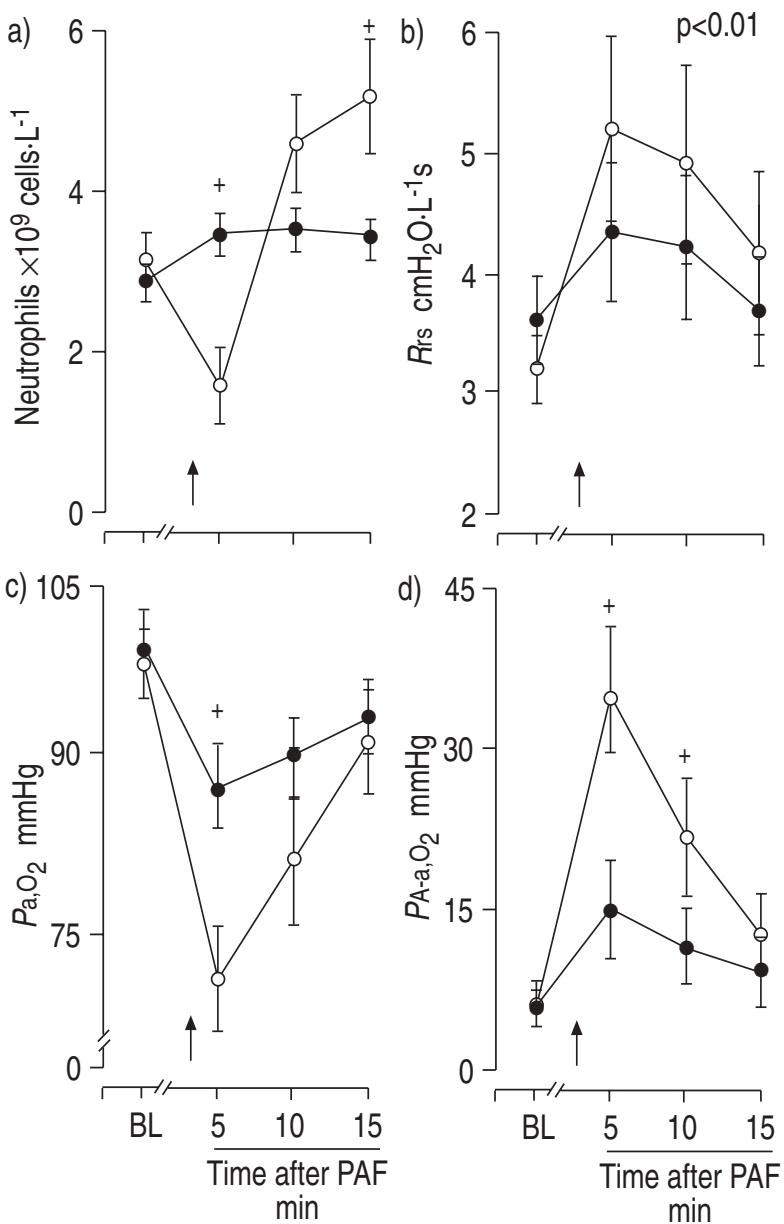

Fig. 1. - Mean ( \pm SEM) time courses of: a) circulating neutrophils $(\mathrm{n}=$ $12)$; b) resistance of the respiratory system $(R \mathrm{rs})(\mathrm{n}=12)$; c) arterial oxygen tension $\left(\mathrm{Pa}_{\mathrm{a}} \mathrm{O}_{2}\right)$; and d) alveolar-arterial pressure difference for oxygen $\left(P \mathrm{~A}-\mathrm{a}, \mathrm{O}_{2}\right) \quad(\mathrm{n}=10)$, after inhaled platelet activating factor $(\mathrm{PAF})$ (arrow) with pretreatment with vehicle (lactose) (O) and PAF receptor antagonist (SR 27417A) (๑) at baseline (BL) and at 5, 15 and 45 min. +. $\mathrm{p}<0.025$. The $\mathrm{p}$-value for $R \mathrm{rs}$ denotes the effect of treatment after PAF challenge. $1 \mathrm{mmHg}=0.133 \mathrm{kPa}$.

\section{Discussion}

Dosing with SR 27417A inhibited all PAF-induced systemic effects and abnormal neutrophil kinetics while effectively minimizing both bronchoconstriction and gas exchange disturbances. By contrast, PAF challenge after vehicle induced all previously reported systemic, neutropenic and lung function abnormalities both in healthy subjects [2-4] and in patients with asthma [5, 6]. Accordingly, SR 27417A is an effective inhibitor of PAF-induced effects on human airways and the dose administered (20 mg) was sufficient, as shown by the significant inhibition of platelet aggregation after SR 27417A. In comparison, in the same model of human asthma after PAF challenge, using identical dosage [6], inhaled salbutamol, but not ipratropium bromide, was efficacious in completely antagonizing all PAF-induced systemic, white cell count and lung function abnormalities. This suggests an anti-oedema effect of short-acting beta-adrenergic agonists that probably attenuates the post-capillary venoconstriction of the bronchial vasculature $[13,14]$. This is the first study to demonstrate inhibition of gas exchange abnormalities with a PAF antagonist.
The data after PAF in patients pretreated with vehicle complement and extend our previous investigations, both in healthy individuals [2-4] and in patients with asthma $[5,6]$. The effects induced by $18 \mu \mathrm{g}$ PAF at $5 \mathrm{~min}$ on cellular and lung function end-point variables after pretreatment with vehicle were quantitatively more profound than those obtained after a lower dose $(12 \mu \mathrm{g})$ of PAF in a similar subset of asthmatic patients [5]. Compared to the challenge with $12 \mu \mathrm{g}$ [5], we observed an approximately twofold increase in the fall of circulating neutrophils $(-49 \%$ versus $-29 \%)$, the decrease of $\mathrm{Pa}, \mathrm{O}_{2}(-28 \%$ versus $-16 \%)$ and the increase of $\operatorname{Rrs}(+62 \%$ versus $+28 \%)$ while the increase of $\mathrm{PA}-\mathrm{a}, \mathrm{O}_{2}$ was even greater $(+473 \%$ versus $+112 \%)$, respectively, indicating a dose-dependent effect of PAF. We speculate that pulmonary gas exchange abnormalities and the simultaneous mild-to-moderate increases of $R$ rs caused by inhaled PAF are more related to narrowing of airway calibre secondary to increased microvascular leakage than to a primary reversible constrictor effect in airway smooth muscle $[2-6,15,16]$.

SR 27417A is a new PAF receptor antagonist that fully and competitively displaces radiolabelled PAF from its high affinity binding sites on rabbit and human platelets with equilibrium dissociation constant $(\mathrm{KD})$ values of $57 \pm$ $0.02 \mathrm{pM}$ and $50 \pm 0.08 \mathrm{pM}$, respectively. On human polymorphonuclear leucocytes SR 27417A inhibits the specific binding of ${ }^{3} \mathrm{H}-\mathrm{PAF}$ to its high affinity receptors $(50 \%$ inhibitory concentration (IC50), $0.17 \pm 0.002 \mathrm{nM}$ ) and displays the same inhibitory pattern already reported for platelets [9]. In animal studies, SR 27417A protects actively sensitized mice from anaphylactic death when given intravenously $5 \mathrm{~min}$ before ovalbumin rechallenge $(50 \%$ protective dose (PD50), $45 \mu \mathrm{g} \cdot \mathrm{kg}^{-1}$ ) or from endotoxininduced death (PD50 $100 \mu \mathrm{g} \cdot \mathrm{kg}^{-1}$ ). A long-lasting protection against endotoxin-induced shock was also found using the oral route in mice at the single dose of 1.0 $\mathrm{mg} \cdot \mathrm{kg}^{-1}[10]$. Clinical data in healthy volunteers indicate that, at the $2.5 \mathrm{mg}$ oral dose, maximum inhibition of PAFinduced platelet aggregation is achieved and lasts over 24 h. Similarly, at the same dose, PAF-induced bronchoconstriction (dosage $36 \mu \mathrm{g}$ ) is also abolished (unpublished data, Report 656.6.033, DARP, Sanofi Recherche, Paris Gentilly, France). Moreover, SR 27417A (10 mg p.o.) significantly protected asthmatic patients against allergen late phase reaction [17].

Although many PAF-receptor antagonists have been tested in animal and human models of allergy and asthma, there have been no data regarding their effects on pulmonary gas exchange disturbances provoked by PAF. In comparison to our findings, BN 52063 showed an inhibitory effect on weal-and-flare response to intradermal injection of PAF and in vitro PAF-induced platelet aggregation [18]. However, one of the most investigated PAF-receptor antagonists, WEB 2086, did not alter allergen challenge responses $[19,20]$, or show differences when compared to placebo, in reducing glucocorticosteroid demands in atopic asthmatics [21]. Another PAF-receptor antagonist, UK 74505, did not alter early or late responses to allergen inhalation or airway hyperresponsiveness to histamine in sensitized patients [22]. Also, its (+)-enantiomer (modipafant) did not show beneficial effects in patients with moderately severe asthma, as assessed by diurnal variations of peak expiratory flow (PEF) or FEV1 [23]. On the other hand, Y24180, a potent PAF-receptor antagonist, slightly improved 
airway hyperresponsiveness in asthmatic patients but had no effect on lung function [24]. More recently, SR 27417A minimally attenuated the late allergen-induced asthmatic response without effects on early response, airway responsiveness or lung function tests [25].

In conclusion, platelet activating factor antagonists remain the best tool available to assess whether platelet activating factor plays an important role in the pathobiology of human asthma, a hypothesis always invoked, but never definitively proven. On the basis of most of the previous pharmacological studies, it is unlikely that platelet activating factor is a conspicuous mediator in asthma or airway hyperreactivity in humans. However, it might be surmised that many studies with platelet activating factor antagonists have failed to antagonize platelet activating factor rather than demonstrating that platelet activating factor is not a cardinal mediator in bronchial asthma. Furthermore, the fact that several of these studies show conflicting data suggests that, in different challenges, either there are different concentrations of platelet activating factor released or perhaps expression of distinct platelet activating factor receptors. The presence of varying receptor subtypes is supported by pharmacological studies with platelet activating factor antagonists that have demonstrated enormous differences in potency in different cell types in the same species [26]. Because lung tissue harbours specific receptors for a wide variety of inflammatory mediators, a single mediator antagonist alone may not display an effective overall antimediator therapeutic response in natural forms of asthma. In this regard, a study with SR 27417A in the setting of patients with spontaneous acute severe asthma would be of great interest to further assess any potential beneficial effects on pulmonary gas exchange abnormalities shown in the current laboratory-induced model of platelet activating factor.

Acknowledgements: The authors are grateful to G. Escolar, from the Servei d'Hemoterapia, Hospital Clínic, Barcelona, for the studies of platelet aggregation, L. de Jover, from the Departament de Salut Pública, Divisió de Ciències de la Salut, Universitat de Barcelona, for statistical advice, E. Bastida, from Sanofi Winthrop, SA, for help in the design of the study and to the technicians of the Lung Function Laboratory for the helpful co-operation.

\section{References}

1. Chung KF. Platelet-activating factor in inflammation and pulmonary disorders. Clin Sci 1992; 83: 127-138.

2. Rodriguez-Roisin R, Félez MA, Chung KF, et al. Plateletactivating factor causes ventilation-perfusion mismatch in man. J Clin Invest 1994; 93: 188-194.

3. Roca J, Félez MA, Chung KF, et al. Salbutamol inhibits pulmonary effects of platelet activating factor in man. Am J Respir Crit Care Med 1995; 151: 1740-1745.

4. Masclans JR, Barberà JA, MacNee W, et al. Salbutamol reduces pulmonary neutrophil sequestration of plateletactivating factor in humans. Am J Respir Crit Care Med 1996; 154: 529-532.

5. Félez MA, Roca J, Barberà JA, et al. Inhaled platelet activating factor worsens gas exchange in mild asthma. Am J Respir Crit Care Med 1994; 150: 369-373.

6. Díaz O, Barberà JA, Marrades R, Chung KF, Roca J, Rodriguez-Roisin R. Inhibition of PAF-induced gas exchange defects by beta-adrenergic agonists in mild asthma is not due to bronchodilation. Am J Respir Crit Care Med 1997; 156: $17-22$.
7. Rodriguez-Roisin R, Roca J. Contributions of multiple inert gas elimination technique to pulmonary medicine. 3: Bronchial asthma. Thorax 1994; 49: 1027-1033.

8. Rodriguez-Roisin R. Acute severe asthma: pathophysiology and pathobiology of gas exchange abnormalities. Eur Respir J 1997; 10: 1359-1371.

9. Helbert JM, Laplace MC, Maffrand JP. Ex vivo effects of SR 27417, a novel PAF antagonist, on rabbit platelet aggregation and ${ }^{3} \mathrm{H}-\mathrm{PAF}$ binding. J Lipid Mediat 1992; 5: 1-12.

10. Helbert JM, Bernat A, Valette G, et al. Biochemical and pharmacological activities of SR 27417A, a highly potent, long acting platelet activating factor receptor antagonist. J Pharmacol Exp Ther 1991; 259: 44-51.

11. Farré R, Peslin R, Rotger M, Navajas D. Human lung impedance from spontaneous breathing frequencies to 32 Hz. J Appl Physiol 1994; 76: 1176-1183.

12. Rotger M, Farré R, Navajas D. Respiratory input impedance up to $256 \mathrm{~Hz}$ in healthy humans breathing foreign gases. J Appl Physiol 1993; 75: 307-320.

13. McDonald DM. Neurogenic inflammation in the respiratory tract: actions of the sensory nerve mediators on blood vessels and epithelium of the airway mucosa. Am Rev Respir Dis 1987; 136: S65-S67.

14. McDonald DM. The ultrastructure and permeability of tracheobronchial vessels in health and disease. Eur Respir $J$ 1990; 3: Suppl. 12, 572s-585s.

15. O'Donnell SR, Barnett CJK. Microvascular leakage due to platelet-activating factor in guinea pig trachea and bronchi. Eur J Pharmacol 1987; 138: 385-386.

16. Yager D, Butler J, Bastacki J, Israel E, Smith G, Drazen JM. Amplification of airway constriction due to liquid filling of airway interstices. J Appl Physiol 1989; 66: 2873-2884.

17. O'Connor BJ, Evans DJ, Coulby LJ, Cluzel M. Attenuation of the late asthmatic response following treatment with a PAF receptor antagonist SR 27417A (abstract). Eur Respir J 1995; 8: Suppl. 19, 377s.

18. Chung KF, McCusker M, Page CP, Dent G, Guinot Ph, Barnes PJ. Effect of a ginkolide mixture (BN 52063) in antagonising skin and platelet response to platelet activating factor in man. Lancet 1987; 1: 248-251.

19. Freitag A, Watson RM, Matsos G, Eastwood C, O'Byrne PM. Effect of a platelet activating factor antagonist, WEB 2086, on allergen induced asthmatic responses. Thorax 1993; 48: 594-598.

20. Abraham WM, Stevenson JS, Garrido R. A possible role of PAF in allergen induced late responses: modification by a selective antagonist. J Appl Physiol 1989; 66: 2351-2357.

21. Spence DP, Johnston SL, Calverley PM, et al. The effect of the orally active platelet activating factor antagonist WEB 2086 in the treatment of asthma. Am J Respir Crit Care Med 1994; 149: 1142-1148.

22. Kuitert LM, Hui KP, Uthayarkumar S, et al. Effects of a platelet activating factor (PAF) antagonist, UK 74505 on allergen-induced early and late response. Am Rev Respir Dis 1993; 147: 82-86.

23. Kuitert LM, Angus RM, Barnes NC, et al. Effect of a novel potent platelet-activating factor antagonist, Modipafant, in clinical asthma. Am J Respir Crit Care Med 1995; 151: 1331-1335.

24. Hozawa S, Haruta Y, Ishioka S, Yamakido M. Effects of a PAF antagonist, Y-24180, on bronchial hyperresponsiveness in patients with asthma. Am J Respir Crit Care Med 1995; 152: 1198-1202.

25. Evans DJ, Barnes PJ, Cluzel M, O'Connor BJ. Effects of a potent platelet-activating factor antagonist, SR 27417A, on allergen-induced asthmatic responses. Am J Respir Crit Care Med 1997; 156: 11-16.

26. Hwang SB. Specific receptors of platelet activating factor, receptor heterogenicity and signal transduction mechanisms. J Lipid Mediat 1990; 2: 123-158. 